\title{
23. THE GENUS BOLBOFORMA DANIELS AND SPIEGLER IN THE OLIGOCENE AND MIOCENE SEDIMENTS OF THE NORTH ATLANTIC AND NORTHERN EUROPE ${ }^{1}$
}

\author{
Carla Müller, Geologisch-Paläontologisches Institut der Universität Frankfurt \\ Dorothee Spiegler, Essen \\ and \\ Léo Pastouret, Centre Océanologique de Bretagne ${ }^{2}$
}

\begin{abstract}
Middle to upper Miocene sediments rich in well preserved specimens of Bolboforma have been recovered during Leg 80 (Goban Spur). This chapter discusses specimens recovered at Site 550, although specimens have been recovered at other Leg 80 sites also (Snyder et al., this vol.). The stratigraphic distribution of the specimens at Site 550 is compared with findings from other areas, including the Bay of Biscay (Leg 48), the Norwegian-Greenland Sea (Leg 38), and northern Europe. Species of Bolboforma show a great variability in morphology, probably as a result of preservation as well as ecological factors. According to their known geographic distribution, they seem to prefer temperate to cold water temperatures.

One new species, Bolboforma pseudohystrix, is described.
\end{abstract}

\section{INTRODUCTION}

Daniels and Spiegler (1974), working with late Oligocene and Miocene sediments from the northwest German Tertiary basin, gave the first description of this problematic group of microfossils. They introduced the genus Bolboforma and discussed in detail its systematic position. Bolboforma have been regarded as test-forming protozoans (Daniels and Spiegler, 1974; Odrzywolska-Bienkowa, 1976); as cysts of algae (Rögl and Hochuli, 1976); and as incertae sedis (Bizon et al., 1977). Specimens have now been found in other areas (mainly in Miocene sediments): the Antarctic (Rögl and Hochuli, 1976); the Atlantic (Leg 82, Sites 558 and 563); the northern high latitudes like the Norwegian-Greenland Sea (Leg 38); the Bay of Biscay and Rockall Bank (Leg 48); Belgium, Poland, and the Mediterranean; and the Vienna Basin (Rögl, pers. comm., 1983).

The genus has been overlooked for a long time, possibly because of the small size of the specimens (120$180 \mu \mathrm{m})$. Specimens have probably been lost in the preparation of samples for the analysis of foraminifers and other microfossils.

\section{MORPHOLOGY}

The maximum diameter of Bolboforma varies from 120 to $180 \mu \mathrm{m}$; therefore, for the investigation of structural details it is necessary to use a scanning electron microscope. The tests of this group are monocrystals, and they show slight birefringence under polarized light. They are very resistant to dissolution, as indicated by their excellent preservation in samples that contain strongly

\footnotetext{
${ }^{1}$ Graciansky, P. C. de, Poag, C. W., et al., Init. Repts. DSDP, 80: Washington (U.S. Govt, Printing Office).

2 Addresses: (Müller) Geologisch-Paläeontologisches Institut der Universitāt Frankfurt, Frankfurt am Main, Germany; (Spiegler) Rosastrasse 60, Essen, Germany; (Pastouret) Centre Octanologique de Bretagne, B.P. 337, Brest Cedex, France.
}

etched and broken planktonic foraminifers (as at Site 550 in Cores 17 and 18). At Site 348 in Cores 27 and 30 (Norwegian-Greenland Sea) they are the only preserved calcareous microfossils.

The tests are more or less spherical (onion or pear shaped) and have a slight aboral flattening. Bolboforma have a circular oral aperture located on the apex of a short terminal neck. The aperture is sometimes closed by a calcite plate (Plate 3, Fig. 12) with a small opening. This plate seals the test lumen at the base of the neck. The presence of an additional aboral opening has been described by Willems (1976); however, no such opening was observed in the specimens examined in this study. Bolboforma have been described as having no true pores (Daniels and Spiegler, 1974), but some specimens in this study from the Norwegian-Greenland Sea show irregularly arranged perforations that might correspond to pores (PI. 1, Figs. 9, 13). Pores have been also observed in specimens of the same species from the Vienna Basin (Rögl, pers. comm., 1983).

The outer wall of some tests is smooth (Bolboforma laevis), but most species show strongly variable ornamentation that may be influenced by such ecological factors as temperature and salinity. The ornamentation includes small knobs, polygonal depressions, simple spines, branching spines, and sharp ridges. The spines are hollow. The ornamentation may be strongly altered by disintegration due to dissolution, diagenesis, or transport.

\section{PALEOENVIRONMENT}

Up to now Bolboforma have been found only in marine sediments. They have been deposited in shallow as well as in deep basins, and according to their known regional distribution (Fig. 1), they seem to prefer temperate to cold water. However, this apparent distribution may be, in part, a result of the sparsity of knowledge about this poorly studied group. 


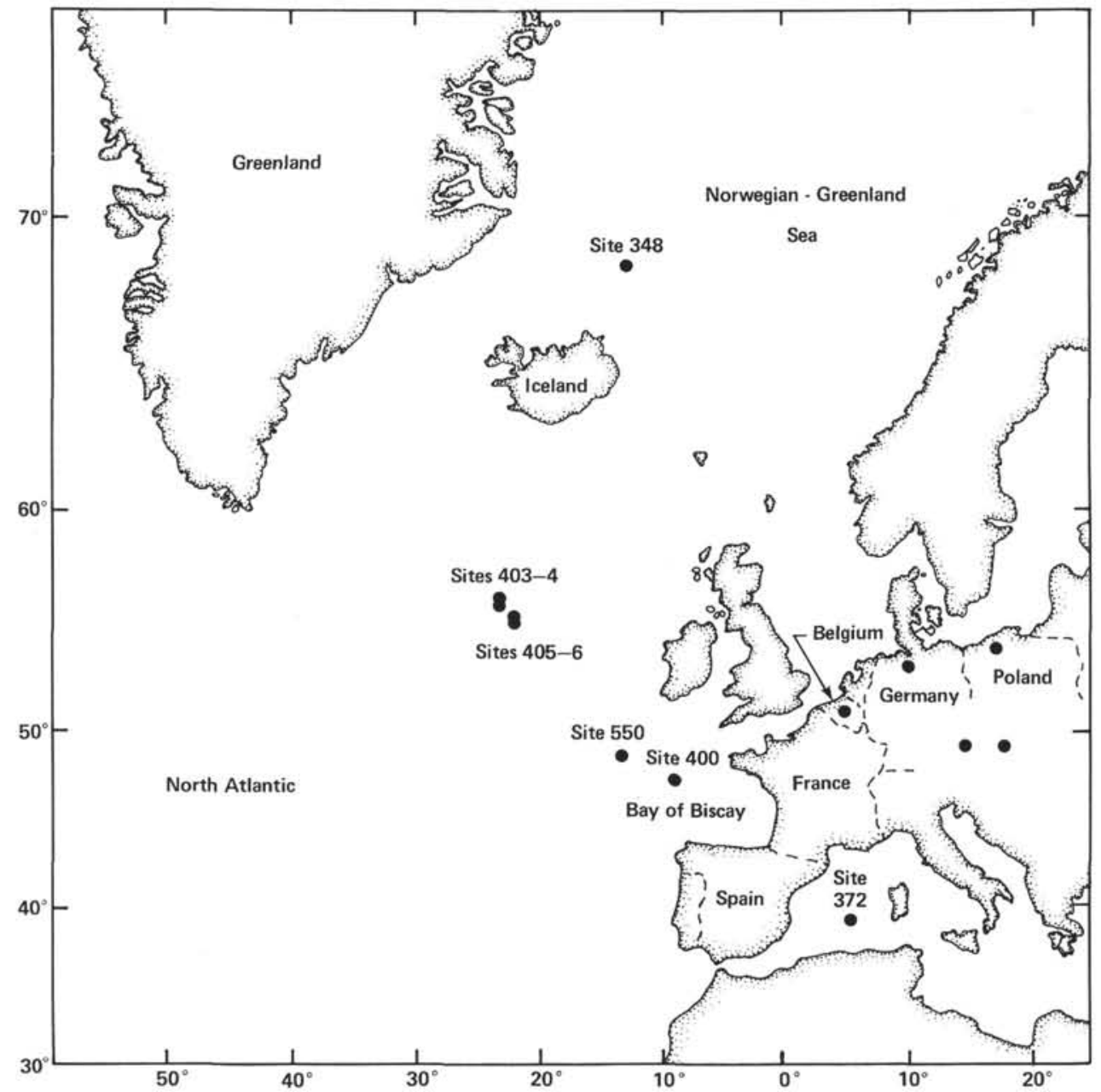

Figure 1. Known distribution of Bolboforma in the Northern Hemisphere.

\section{STRATIGRAPHIC DISTRIBUTION}

Little is known concerning the stratigraphic range of the different species and their value for biochronology. What is known from the literature is summarized in Table 1. Each species seems to have a rather long range, and species abundance seems to be controlled by ecology. Daniels and Spiegler (1974) described spherical forms as more characteristic of older rocks (late Oligocene to early Miocene) and aborally flattened forms as more typical of the middle and late Miocene.

Bolboforma spiralis is common in the upper Oligocene sediments of northwest Germany (Daniels and Spiegler, 1974). This species is rare in the lower Miocene sediments of that region. However, B. spiralis is common in the middle Miocene sediments (nannoplankton Zone NN6) recovered from Site 550, where it occurs together with common $B$. laevis. B. spiralis has not been reported from the lower Miocene of the Antarctic (Rögl and Hochuli, 1976) or from the Norwegian-Greenland Sea. On the other hand, the common occurrence of $B$. metzmacheri in the upper Miocene sediments of Germany, as described by Daniels and Spiegler (1974), seems to be more typical, as also mentioned by Willems (1976) from Belgium. An acme for this species was also ob- served in the upper Miocene at Site 400 in the Bay of Biscay. At the Rockall Plateau, B. metzmacheri is reported (in nannoplankon Zone NN11) only at Site 404; it was not found at Site 403 or 406 (Murray, 1979). This species was accompanied by $B$. spiralis (rare), $B$. clodiusi (common), B. laevis (common), B. aculeata (rare), and $B$. intermedia (rare). Recently Bolboforma have been found also in early Oligocene sediments (Spiegler, pers. comm., 1983).

Many more data are needed to improve our knowledge of the stratigraphic and regional distribution of the different species of Bolboforma.

\section{SYSTEMATIC DESCRIPTION}

Bolboforma cf. aculeata Daniels and Spiegler, 1974 (P1. 2, Figs. 8-10)

Bolboforma aculeata Daniels and Spiegler, 1974, p. 65, pl. 8, figs. 1-3.

Remarks. The specimens studied do not have a flattened aboral side like Bolboforma aculeata.

Occurrence. Middle Miocene, Site 550, Core 18

Bolboforma clodiusi Daniels and Spiegler, 1974

(Pl. 1, Figs. 7, 8)

Lagena hystrix Teuss, 1922, p. 109.

Bolboforma clodiusi Daniels and Spiegler, 1974, p. 63, pl. 7, figs. 4-6. 
Table 1. Stratigraphic distribution of Bolboforma.

\begin{tabular}{|c|c|c|c|c|c|c|c|c|}
\hline Species & $\begin{array}{l}\text { Northwest } \\
\text { Germany }\end{array}$ & Belgium & Poland & $\begin{array}{c}\text { Rockall } \\
\text { Plateau } \\
\text { (Sites 403-406) }\end{array}$ & $\begin{array}{l}\text { Bay of Biscay } \\
\text { (Site 400) }\end{array}$ & $\begin{array}{l}\text { Goban Spur } \\
\text { (Site 550) }\end{array}$ & $\begin{array}{l}\text { Norwegian- } \\
\text { Greenland Sea } \\
\text { (Site 348) }\end{array}$ & $\begin{array}{l}\text { Antarctica } \\
\text { (Site 325) }\end{array}$ \\
\hline B. spiralis & $\begin{array}{l}\text { upper Oligocene } \\
\text { (common) }\end{array}$ & $\begin{array}{l}\text { upper Miocene } \\
\text { (rare) }\end{array}$ & & upper Miocene & & $\begin{array}{l}\text { middle Miocene } \\
\text { (common) }\end{array}$ & & \\
\hline B. laevis & $\begin{array}{l}\text { Miocene (common, } \\
\text { upper Mioc.) }\end{array}$ & $\begin{array}{l}\text { upper Miocene } \\
\text { (few) }\end{array}$ & & upper Miocene & middle-upper Miocene & middle Miocene & & lower Miocene \\
\hline B. metzmacheri & $\begin{array}{l}\text { upper Miocene (com- } \\
\text { mon) }\end{array}$ & $\begin{array}{l}\text { upper Miocene } \\
\text { (common) }\end{array}$ & upper Miocene & upper Miocene & $\begin{array}{l}\text { middle-upper Miocene } \\
\text { (common, upper } \\
\text { Miocene) }\end{array}$ & middle Miocene & & \\
\hline B. clodiusi & $\begin{array}{l}\text { Miocene (common, } \\
\text { upper Mioc.) }\end{array}$ & $\begin{array}{l}\text { upper Miocene } \\
\text { (rare) }\end{array}$ & & upper Miocene & middle Miocene & middle Miocene & & $\begin{array}{l}\text { lower Miocene } \\
\text { (common) }\end{array}$ \\
\hline B. reticulata & $\begin{array}{l}\text { Miocene (common, } \\
\text { middle Mioc.) }\end{array}$ & $\begin{array}{l}\text { upper Miocene } \\
\text { (rare) }\end{array}$ & & & & middle Miocene & & \\
\hline $\begin{array}{l}\text { B. aculeata } \\
\text { B. armata }\end{array}$ & $\begin{array}{l}\text { middle-upper Miocene } \\
\text { middle-upper Miocene }\end{array}$ & & & upper Miocene & & & & \\
\hline B. intermedia & middle Miocene & & & upper Miocene & middle Miocene & & & \\
\hline B. rotunda & $\begin{array}{l}\text { upper Oligocene, } \\
\text { lower Miocene }\end{array}$ & upper Miocene & upper Miocene & & & middle Miocene & & $\begin{array}{l}\text { lower Miocene } \\
\text { (few) }\end{array}$ \\
\hline $\begin{array}{l}\text { B. irregularis } \\
\text { B. pseudohystrix }\end{array}$ & upper Oligocene & & & & & middle Miocene & lower Miocene & \\
\hline B. spinosa & $\begin{array}{l}\text { upper Oligocene, } \\
\text { lower Miocene }\end{array}$ & & & & & middle Miocene & & $\begin{array}{c}\text { lower Miocene } \\
\text { (common) }\end{array}$ \\
\hline
\end{tabular}

Bolboforma clodiusi Daniels and Spiegler, Rögl and Hochuli, 1976, p. 714 , pl. 1, figs. 4-6; pl. 2, fig. 3 .

Remarks. Figure 7 shows a specimen with broken spines similar to specimens described from Miocene sediments from northwest Germany. The specimen in Figure 8 is better preserved, having spines that bifurcate at their tips.

Occurrence. Miocene.

\section{Bolboforma irregularis Daniels and Spiegler, 1974}

(PI. 3, Figs. 3-11)

Bolboforma irregularis Daniels and Spiegler, 1974, p. 69, pl. 10, figs. $4,5$.

Remarks. Bolboforma irregularis was described from poorly preserved upper Oligocene material from northwest Germany. The present material is much better preserved and shows that the tips of the irregularly arranged ridges and knobs are bifurcated (Pl. 3, Figs. 8, 9). Forms transitional between $B$. irregularis and $B$. spiralis can be observed in middle Miocene sediments from the northeast Atlantic (Site 550, Core 18; Pl. 3, Figs. 3-6).

Occurrence. Upper Oligocene to middle Miocene.

\section{Bolboforma laevis Daniels and Spiegler, 1974}

$$
\text { (Pl. 1, Fig. 4) }
$$

Bolboforma laevis Daniels and Spiegler, 1974, p. 64, pl. 7, figs. 7-9; pl. 10 , fig. 6 .

Remarks. Bolboforma laevis is common in the middle Miocene sediments recovered from Site 550 .

Occurrence. Miocene.

\section{Bolboforma metzmacheri Daniels and Spiegler, 1974}

(Pl. 1, Figs. 1-3)

Lagena metzmacheri Clodius, 1922, p. 108, pl. 1, fig. 2.

Bolboforma metzmacheri (Clodius) Daniels and Spiegler, 1974, p. 7, figs. 1-3.

Remarks. The typical polygonal depressions covering the test of this species are variable, depending upon the preservation of the material. The specimens from the upper Miocene sediments of the Bay of Biscay (Site 400) are somewhat more elongated than forms described from northwest Germany.

Occurrence. Common in the upper Miocene, rare in the middle Miocene.

Bolboforma pseudohystrix Müller and Spiegler, n. sp.

$$
\text { (Pl. 1, Figs. 9-13) }
$$

Lagena hystrix Reuss-Clodius, 1922, p. 109.

Holotype. Plate 1, Figure 12.

Paratypes. Plate 1, Figures 9-11, 13.

Type locality. Site 348 , Core 27 , Norwegian-Greenland Sea.

Type level. Lower Miocene.
Diagnosis. Test slightly flattened, with short neck and round aperture. The ornamentation consists of polygonal, mostly triangular depressions with spines at the points of intersection.

Description. The ornamentation consists of 4- to 6-sided spines that are connected by a polygonal reticulation (mostly triangular). The ribs of the network flank the spines, which are partially furcated at their tips.

Remarks. Clodius (1922) described forms as Lagena hystrix from the "Glimmerton" in northern Germany as having an "unregelmässiges Netzwerk auf dessen Leisten Stacheln stehen." Daniels and Spiegler $(1974$, p. 63$)$ described these forms with spines but without a polygonal network as Bolboforma clodiusi. The present material makes it possible to show that $B$. clodiusi and Lagena hystrix Reuss sensu clodius are two different species. $B$. pseudohystrix differs from $B$. clodiusi by the presence of a polygonal network and from $B$. reticulata by the presence of different shaped polygonal depressions and spines. $B$. aculeata has a more irregular ornamentation.

The same species was found in middle Miocene sediments from the Vienna Basin (Rögl, pers. comm., 1983).

Occurrence. Lower-middle Miocene, Norwegian-Greenland Sea, Leg 38, Site 348.

\section{Bolboforma reticulata Daniels and Spiegler, 1974}

$$
\text { (Pl. 1, Figs. 5, 6) }
$$

Bolboforma reticulata Daniels and Spiegler, p. 64, pl. 7, figs. 10, 11. Remarks. Only few specimens of Bolboforma reticulata were observed in the middle Miocene sediments at Site 550.

Occurrence. Miocene, more common within the middle Miocene.

\section{Bolboforma spinosa Daniels and Spiegler, 1974}

$$
\text { (PI. 1, Figs. 14-18) }
$$

Bolboforma spinosa Daniels and Spiegler, 1974, p. 67, pl. 9, figs. 3, 4

Remarks. Bolboforma spinosa was described from poorly preserved upper Oligocene material from northwest Germany. The spines are numerous, round in cross section, of variable diameter and length (Pl. 1, Figs. 14-18), and have partially furcated tips. The maximum length of the spines is 20 to $30 \mu \mathrm{m}$.

Occurrence. Upper Oligocene to middle Miocene.

\section{Bolboforma spiralis Daniels and Spiegler, 1974}

(Pl. 2, Figs. 1-7, 11-16; Pl. 3, Figs. 1, 2, 12)

Bolboforma spiralis Daniels and Spiegler, 1974, p. 68, pl. 9, figs. 5, 8; pl. 10, figs. 1-3.

Remarks. Bolboforma spiralis has been described from the early Miocene sediments of northwest Germany. The rich material obtained from Site 550 has shown that there are a number of varieties with transitional forms. $B$. spiralis is characterized by a distinct ornamentation with spirally arranged knobs and ridges. The outer rim of this ornamentation may be decomposed and show closely arranged spines with 
furcations at the tips. At the base the spines are connected to a ridge. Specimens transitional between $B$. spiralis and $B$. irregularis have isolated elements that are spirally arranged (Pl. 3, Figs. 3-6). The elements of the ornamentation of $B$. cf. aculeata are more delicate and irregularly distributed on the test. The specimens of the spiralis group very often have a thin plate with a small opening that seals the test below the aperture (Pl. 3, Fig. 12). In Figure 12 the aperture is broken. The specimen is probably a Bolboforma with two chambers, as described by Daniels et al. (1981). However, the second chamber would be significantly smaller.

Occurrence. Upper Oligocene to middle Miocene.

The type specimens are deposited in the Natur-Museum and Forschungs-Institut Senckenberg, Frankfurt-am-Main, Germany, under catalogue numbers SM. B.

\section{ACKNOWLEDGMENTS}

One of the authors (C. Müller) wants to thank the Deutsche Forschungsgemeinschaft for financial support. SEM-photographs were taken with a Stereoscan Mark 2, which was provided to the Geologisch-Paläontologisches Institut der Universität Frankfurt am Main by the VW-Stiftung. The authors thank Prof. Dr. J. W. Murray (Exeter, England) and Dr. F. Rögl (Vienna, Austria) for reviewing this paper.

\section{REFERENCES}

Bizon, G., Taugoutdeau-Lantz, J., and Wright, R., 1977. Présence d'algues enkystées: Pachysphaera et de microfossiles d'affinités in- certaines: Bolboforma dans le Miocène de Méditerranée. Rev. Micropaleontol., 20:104-146.

Daniels, C. H. von, and Spiegler, D., 1974. Bolboforma n. gen. (Protozoa?)-eine neue stratigraphisch wichtige Gattung aus dem Oligozän/Miozän Nordwestdeutschlands. Palaeontol. Z., 48:57-76.

Daniels, C. H. von, Spiegler, D., and Bijvank, G., 1981. Zweikammerige Bolboforma (Mikroproblematica, Protozoa?). Palaeontol. Z., 55:175-177.

Murray, J. W., 1979. Cenozoic biostratigraphy and paleoecology of Sites 403 to 406 based on the foraminifers. In Montadert, L., Roberts, D. G., et al., Init. Repts. DSDP, 48: Washington (U.S. Govt. Printing Office), 415-430.

Odrzywolska-Bienkowa, E., 1976. On some species of the genus Bolboforma (Protozoa?) from the Miocene of Poland. Kwartalnik Geol., 20:551-558.

Rögl, F., and Hochuli, P., 1976. The occurrence of Bolboforma, a probable algae cyst, in the Antarctic Miocene of DSDP Leg 35. In Hollister, C. D., Craddock, C., et al., Init. Repts. DSDP, 35: Washington (U.S. Govt. Printing Office), 713-719.

Willems, W., 1976. The genus Bolboforma von Daniels and Spiegler in the upper Miocene of northern Belgium. Bull. Soc. Belge Geol., 85:31-38.

Date of Initial Receipt: May 3, 1983

Date of Acceptance: August 11, 1983 


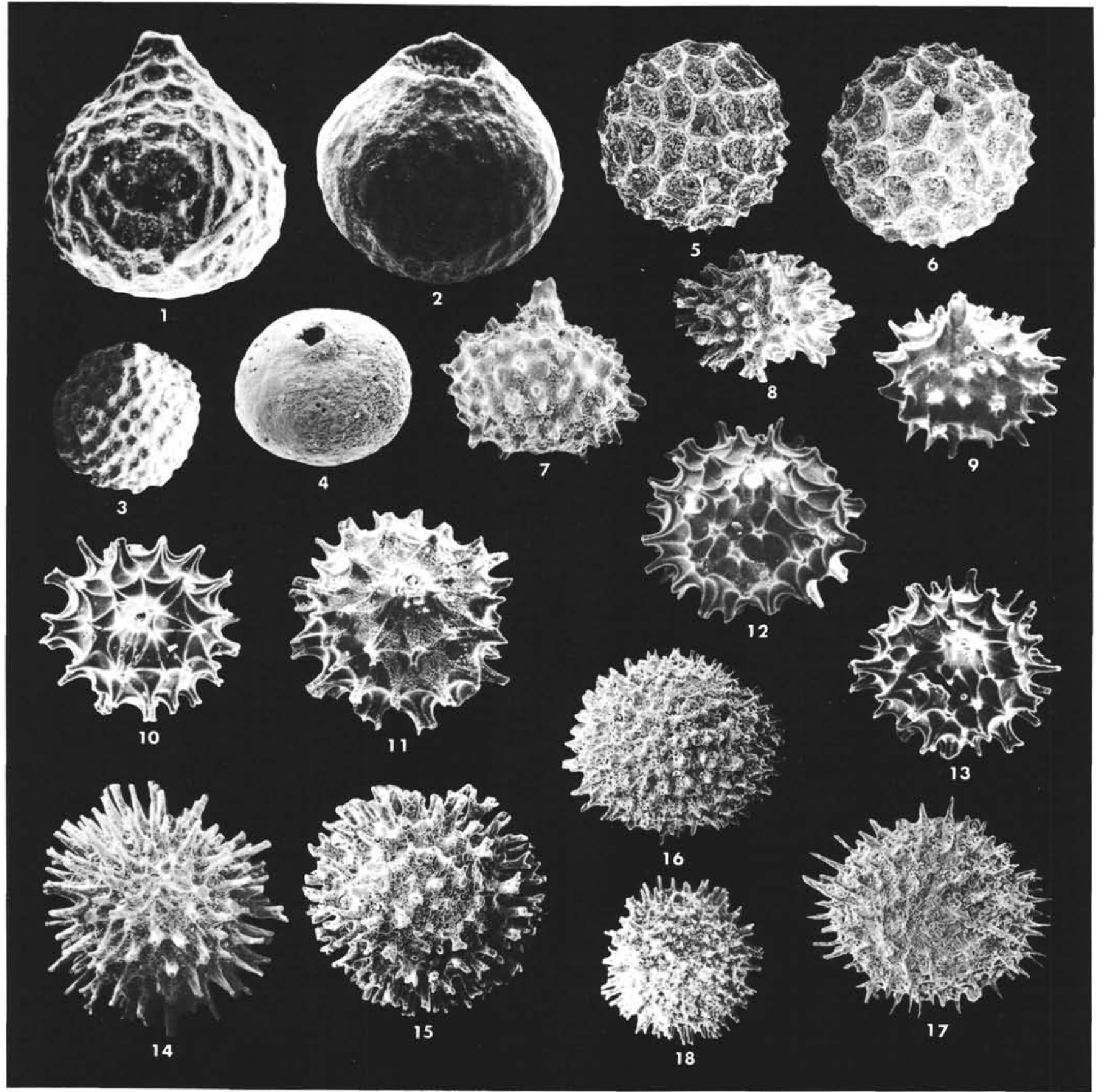

Plate 1. Oligocene to Miocene Bolboforma. 1-3. Bolboforma metzmacheri Daniels and Spiegler, 1974. Aboral flattening and polygonal depressions. (1-2) $\times 291$, Leg 48 Sample 400-27-1, 127-128 cm (2, broken aperture), (3) $\times 204$, Sample 550-18,CC, middle Miocene. 4. Bolboforma laevis Daniels and Spiegler, 1974. Aboral flattening and smooth surface. $\times 243$, Sample 550-18,CC, middle Miocene. 5-6. Bolboforma reticulata Daniels and Spiegler, 1974. Aboral flattening and coarse network of mostly pentagonal depressions. Sample 550-18,CC, middle Miocene. (5) $\times 180$, (6) $\times 243$. 7-8. Bolboforma clodiusi Daniels and Spiegler, 1974. Aboral flattening and irregularly arranged angular spines. (7) $\times 243$, Sample 550-18,CC, middle Miocene, (8) $\times 315$, Sample 550-1-3, 73-76 cm, middle Miocene. 9-13. Bolboforma pseudohystrix Müller and Spiegler n. sp., aboral flattening and polygonal (mostly triangular) depressions covered with angular spines, $\times 223$, Sample $348-27, C C$, lower Miocene. (12) Holotype. Aboral flattened polygonal (mostly triangular) depressions covered with angular spines. 14-18. Bolboforma spinosa Daniels and Spiegler, 1974. Spherical test with numerous fine spines. $(14-15)$ Sample $550-17-3,73-76 \mathrm{~cm}(14, \times 228 ; 15, \times 243),(16) \times 243$, Sample 550-17,CC, $(17-18)$ Sample 550-18,CC, middle Miocene $(17, \times 165 ; 18, \times 218)$. 


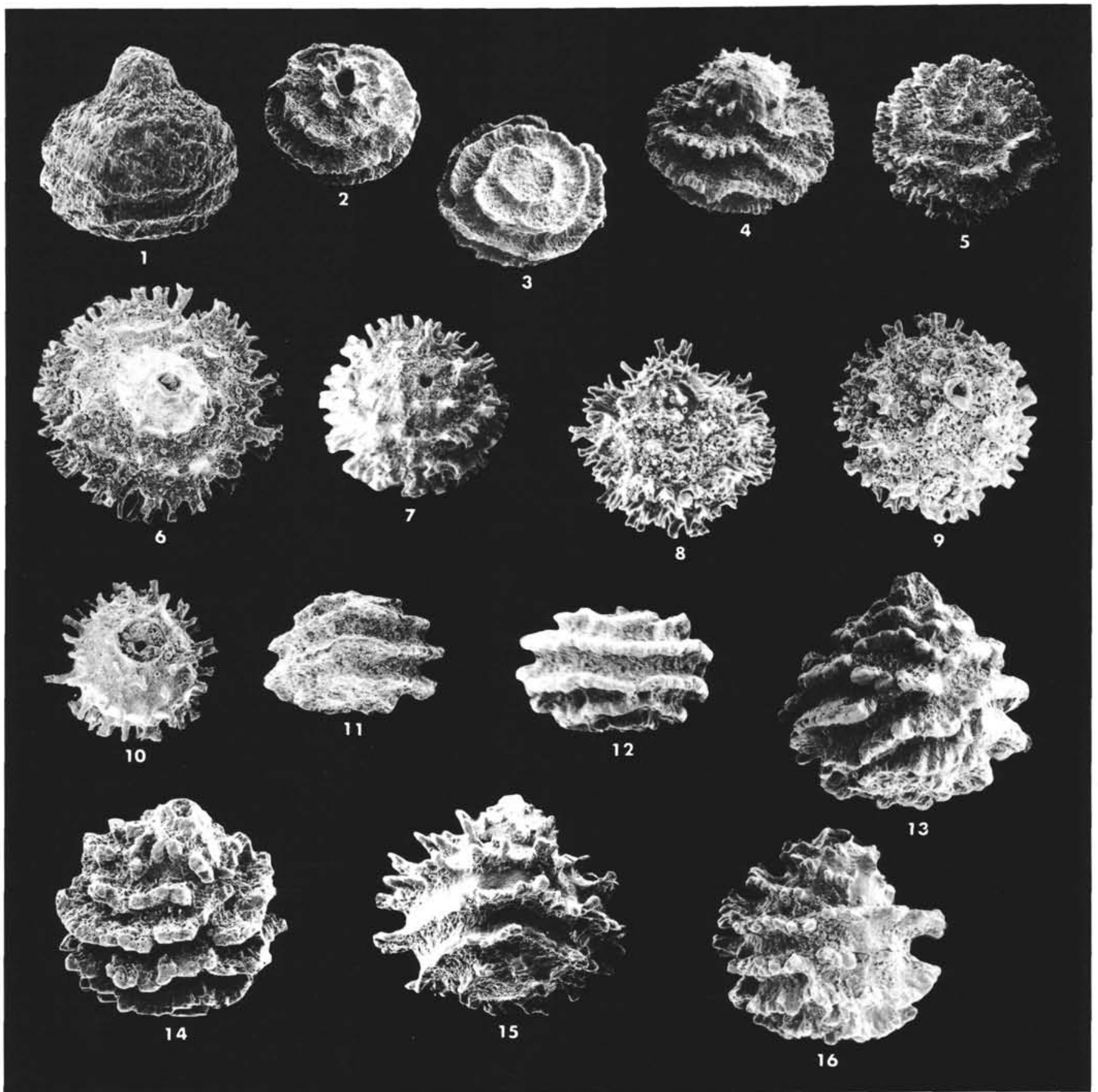

Plate 2. Oligocene and Miocene Bolboforma. 1-7. Bolboforma spiralis Daniels and Spiegler, 1974. Onion-shaped to spherical test with fine spiral sculpture. (1) $\times 243$, Sample 550-17,CC, (2) $\times 204$, Sample 550-18,CC, (3) $\times 175$, Sample 550-18-2, 40-42 cm, (4) $\times 155$, Sample 550-18,CC, $(5,7)$ Sample 550-18,CC $(5, \times 175 ; 7, \times 204)$. (6) $\times 223$, Sample 550-17,CC. 8-10. Bolboforma cf. aculeata Daniels and Spiegler, 1974. Onionshaped to spherical test and irregular spinose ornamentation. Sample $550-18, C C$. $(8) \times 194,(9) \times 315,(10) \times 146$. 11-16. Bolboforma spiralis Daniels and Spiegler, 1974. Onion-shaped to spherical test with coarse spiral sculpture. $(11-12,16) \times 146$, Sample $550-18, C C,(13-15) \times 243$, Sample $550-17-3,73-76 \mathrm{~cm}$. 


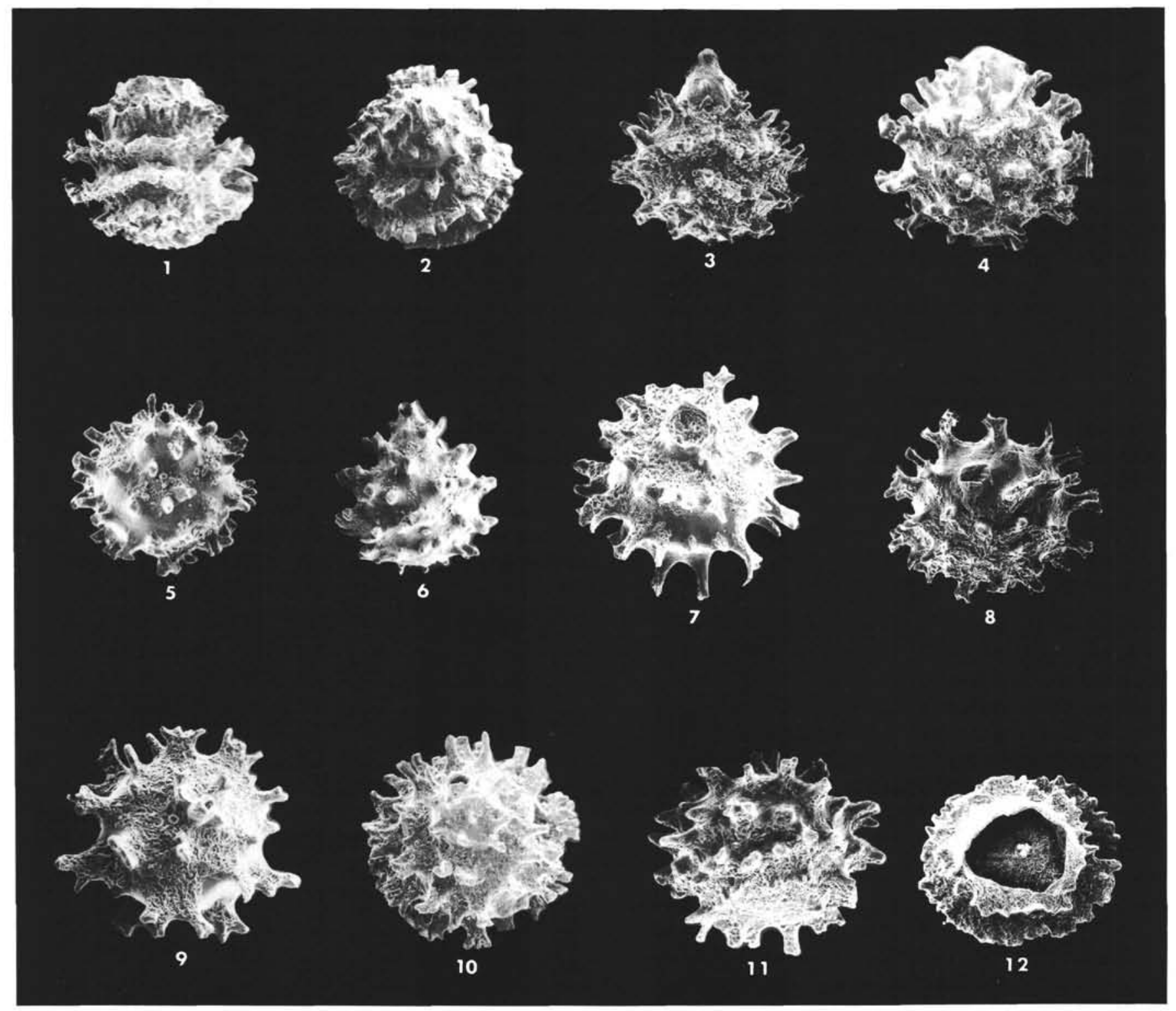

Plate 3. Oligocene and Miocene Bolboforma. 1-2. Bolboforma spiralis Daniels and Spiegler, 1974 , Sample $550-18, C C .(1) \times 243$, $(2) \times 184$. 3-11. Bolboforma irregularis Daniels and Spiegler, 1974. (3-6) Forms transitional between Bolboforma irregularis and Bolboforma spiralis. Onion-shaped to spherical test with coarse spiral sculpture decomposed in isolated spines and ridges, Sample 550-18,CC. (3, $\times 170 ; 4, \times 243 ; 5-6$, $\times 233)$. $(7-9,11)$ Sample 550-17-3, 73-76 cm $(7,9,11, \times 233 ; 8, \times 209) .(10) \times 243$, Sample 550-18,CC. 12. Bolboforma spiralis Daniels and Spiegler, 1974. Broken aperture showing the calcite plate, $\times 243$, Sample $550-17-3,73-76 \mathrm{~cm}$. 